New Developments in Sheep Production

Occasional Publication No. 14-British Society of Animal Production 1990

edited by C. F. R. Slade and T. L. J. Lawrence

\title{
EFFECTS OF SUPPLEMENTATION UPON THE VOLUNTARY INTAKE AND GROWTH OF STORE LAMBS GIVEN MAIZE SILAGE
}

\author{
M. A. KOSSAIBATI and M. J. BRYANT \\ Department of Agriculture, University of Reading, Earley Gate, Reading RG6 2AT
}

\section{INTRODUCTION}

$\mathbf{F}^{\circ}$ orage maize silage appears to have received scant attention as a possible source of forage for finishing store lambs during the winter period. There is little or no information on intakes or the likely effect that the addition of supplements may have on intake and growth. As maize silage is relatively low in crude protein, it seems most likely that some supplement of nitrogen or protein could be necessary. Moreover, it has been demonstrated that supplements of foods rich in rumen undegradable protein, when given with other forages such as grass silage or chemically treated straw, will enhance lamb performance (Yilala and Bryant, 1985; Hassan and Bryant, 1986a and b). The experiment described here was carried out to establish the intake and growth responses of store lambs to supplements of fish meal when given a basal diet of maize silage and two levels of concentrate.

\section{MATERIAL AND METHODS}

\section{Experimental design}

The experiment was arranged as a randomized block with a $3 \times 2$ factorial design. Three levels of inclusion of fish meal $(0,28$ and $56 \mathrm{~g}$ dry matter (DM) per $\mathrm{kg}$ diet DM) and two levels of concentrate supplementation (2.5 (L) and $10 \cdot 0(\mathrm{H}) \mathrm{g} / \mathrm{kg}$ live weight) were investigated. Fifty-six lambs (Suffolk $\sigma^{\prime} \times$ (Bluefaced Leicester $\sigma^{\top} \times$ Swaledale $q$ ) $q$ crosses between 8 and 9 months of age and with average weight of 35.4 (s.d. 2.07) kg at the start of the experiment), with an equal number of females and castrated males, were randomly allocated from live weights and sex blocks to give eight lambs per cell of the experimental design and eight (the two lighter and the two heavier of each sex) lambs as a preliminary slaughter groups to provide a prediction of carcass weight. Twenty-four lambs of approximately equal live weight were selected for the determination of diet digestibility and nitrogen balance in weeks 3 and 5 of the experiment, two lambs, one of each sex from each treatment, being represented at each time.

\section{Diets}

The forage maize variety was Leader. The crop was harvested with a precision-chopper and ensiled without additives. The composition of the silage is shown in Table 1. The composition of the ingredients of the foods used in the concentrate supplements is shown in Table 2. Table 3 shows the composition of the diets. In deciding upon the rationing of the lambs, and therefore the composition of the supplements, the predicted intakes of the lambs were first calculated using the equation for mixed diets presented by the Agricultural Research Council (ARC, 1980). The forage : concentrate ratios desired were $90: 10$ and $60: 40$. Fish meal replaced urea isonitrogenously such that the ratios of urea to fish meal in the diet were $1: 0,1: 1$, or $1: 4$, with the ratio of rumen degradable nitrogen (RDN) to metabolizable energy (ME) ( $\mathrm{g} / \mathrm{MJ})$ being equal to or in excess of $1.34 \mathrm{~g}$ in all diets (ARC, 1984). Some slight increase in total $\mathrm{N}$ concentration occurred with increasing inclusions of fish meal because of the increasing concentrations of rumen

TABLE 1

Chemical composition of the maize silage

Dry matter (DM) $(\mathrm{g} / \mathrm{kg}) \quad 269$

$\mathrm{pH}$

Ash (g/kg DM)

Total nitrogen ( $\mathrm{g} / \mathrm{kg} \mathrm{DM})$

Ammonia-N (g/kg total nitrogen)

Water-soluble carbohydrate (g/kg DM) 13

Starch (g/kg DM)

Organic acids (g/kg DM)

Acetic

N-butyric

Lactic

Propionic

TABLE 2

Chemical composition of the foodstuffs

$\begin{array}{lccc} & \begin{array}{c}\text { Dry matter } \\ (\mathrm{DM}) \\ (\mathrm{g} / \mathrm{kg}\end{array} & \begin{array}{c}\text { Total } \\ \text { nitrogen }\end{array} & \text { Ash } \\ & & & \\ & \text { fresh weight }) & (\mathrm{g} / \mathrm{kg} \mathrm{DM}) & (\mathrm{g} / \mathrm{kg} \mathrm{DM}) \\ \text { Barley } & 851 & 17 \cdot 7 & 40 \\ \text { Fish meal } & 902 & 117 \cdot 1 & 187\end{array}$


TABLE 3

Composition of the diets

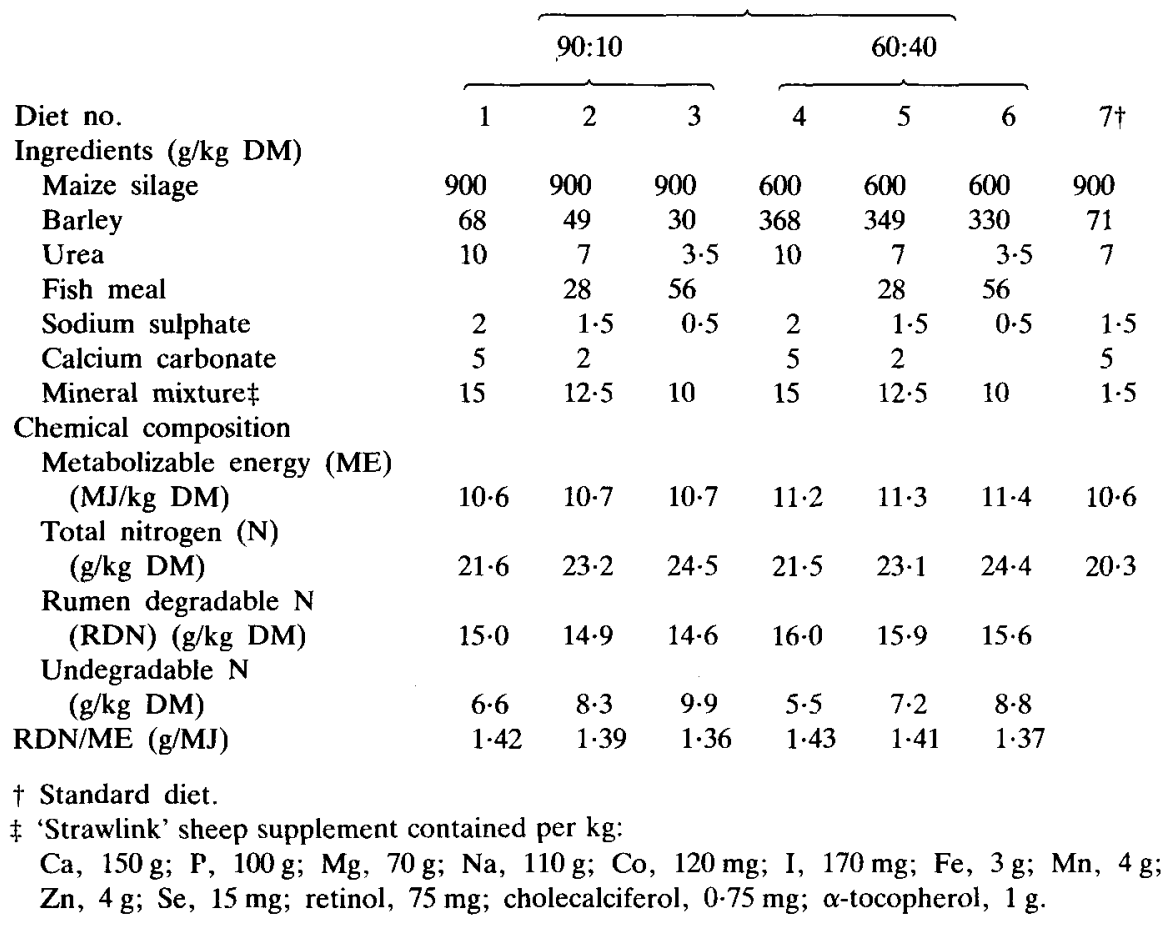

undegradable nitrogen (UDN). A standard diet (shown as diet 7 in Table 3) was formulated to be given to all lambs during the adaptation period.

\section{Procedure}

The lambs were dosed with anthelmintics, individually penned on wood shavings and randomly allocated to treatment. All were given increasing quantities of maize silage and the standard diet up to $10 \mathrm{~g}$ DM per $\mathrm{kg}$ live weight for the $\mathrm{H}$ concentrate treatment or $2.5 \mathrm{~g} \mathrm{DM}$ per $\mathrm{kg}$ live weight for the $\mathrm{L}$ concentrate treatment for 2 weeks. At the end of this period all lambs were weighed on 2 days consecutively, the preliminary slaughter group was killed $24 \mathrm{~h}$ after their final food had been given, the cold carcass weights obtained and the experimental diets introduced. The concentrate supplements were given according to predicted voluntary DM intakes, adjustments being made weekly according to live weight. The daily intakes of maize silage were measured and the previous day's intakes plus proportionately $0 \cdot 15$ were given subsequently, the silage being taken fresh from the clamp.
Foud intake and live-weight gain were measured for 42 days, at the end of which the lambs were weighed on 2 days consecutively and slaughtered $24 \mathrm{~h}$ after the last food had been given. For the digestibility and $\mathrm{N}$ balance determinations the lambs were allowed 4 days to adapt to the metabolism crates and faeces, urine and refused food were collected for 7 days. Urine was collected into $50 \mathrm{ml} \mathrm{H}_{2} \mathrm{SO}_{4}$. Ten per cent aliquots of urine and faeces were retained daily at $-15^{\circ} \mathrm{C}$ for subsequent analysis.

\section{Chemical analysis}

Samples of the maize silage, the diets, food refusals and faeces were freeze-dried and then oven dried at $80^{\circ} \mathrm{C}$ for $24 \mathrm{~h}$ to determine DM. Samples were then ashed at $550^{\circ} \mathrm{C}$ for $20 \mathrm{~h}$. Gross energy (GE) was established by adiabatic bomb calorimeter. Total $\mathrm{N}$ was measured by combustion chemistry using a thermal conductivity detector (LECO FP-228). Urinary total $\mathrm{N}$ was determined with sulphuric acid. The volatile fatty acid concentrations in the silage were measured by gas chromatography after extraction with sulphuric acid $(0.15 \mathrm{ml} / \mathrm{l})$. The ammonia $\mathrm{N}$ in the silage extract was measured using an ammonia electrode. 


\section{Statistical analysis}

A regression line was fitted to the live weights and carcass weights of the lambs of the preliminary slaughter groups to provide a prediction of the carcass weights of the lambs at the beginning of the feeding period. Live-weight gain was determined by regressing live weight on time. Voluntary intake, digestibility coefficients and nitrogen balance statistics were examined using analysis of variance with the live weight at the start of the feeding period as a covariate. Variation was partitioned into sex, fish-meal level, concentrate level, fish meal $\times$ concentrate interactions and diet $x$ sex interactions.

\section{RESULTS}

All the lambs remained healthy and completed the experiment. No statistically significant interactions were found between concentrate and fish-meal level and therefore the results are presented as main effects.

\section{Voluntary intake (Table 4)}

Maize silage DM intakes were considerably reduced by the $\mathrm{H}$ level of concentrate offered $(P<0.001)$ but the inclusion of fish meal had no effect on silage intake. Total DM intakes were not affected by supplement. The tabulated values show the mean daily intakes throughout the experiment. Intakes were also examined for the first and second 3-week periods of the experiment. The trends for the effects of the treatments during these two subperiods are the same as for the overall experiment, except the $H$ level of supplementation did promote greater total DM intakes during the last half of the experiment ( 68 compared with $63 \mathrm{~g} / \mathrm{kg} \mathrm{M}^{0-75}$; s.e.d. $=2 \cdot 3$ ).

\section{Live-weight and carcass gains (Table 5)}

The $\mathrm{H}$ level of supplementation and the inclusion of fish meal promoted greater gains during the second half of the experiment $(P<0.05$ for supplement level and $P<0.01$ for fish meal). However, only fish meal was associated with greater gains throughout the experiment $(P<0.05)$. No advantages in gains were seen above the intermediate level of inclusion of fish meal. Final live weights did not differ statistically between treatments.

Carcass gains and final carcass weights were improved both by the level of supplementation and the inclusion of fish meal $(P<0 \cdot 05)$. The major part of the response to fish meal was achieved by the intermediate level of inclusion. The small improvement in killing-out proportion associated with the $\mathrm{H}$ level of supplementation was significant $(P<0.05)$.

While the level of supplementation had no significant effect on the efficiency of conversion of diet DM to live-weight gain, the inclusion of fish meal considerably improved efficiency $(P<0.01)$.

\section{Digestibility coefficients and $N$ balance}

The digestibility coefficients of DM, organic matter (OM) and GE were not affected by treatment, the mean being $0.65,0.67$ and 0.70 respectively. However, when the digestibility coefficients were examined with intake as a covariate, then the $H$ level of supplementation was associated with enhanced digestibilities (DM, $P<0 \cdot 01$; OM, $P<0.01 ;$ GE, $P<0.05)$.

Nitrogen balance data are shown in Table 6 . The $\mathrm{H}$ level of supplementation resulted in greater losses of $\mathrm{N}$ in the faeces $(P<0.05)$ but, as a result of higher $\mathrm{N}$ intake, greater $\mathrm{N}$ retention $(P<0.05)$. The inclusion of fish meal also resulted in higher $\mathrm{N}$ intakes, and increased

TABLE 4

Effect of level of concentrate offered and fish-meal supplementation on voluntary intake

\begin{tabular}{|c|c|c|c|c|c|c|c|}
\hline \multirow{3}{*}{$\begin{array}{l}\text { Silage dry-matte } \\
\text { intake }\end{array}$} & \multicolumn{3}{|c|}{ Level of concentrate } & \multicolumn{4}{|c|}{$\begin{array}{l}\text { Fish meal supplementation } \\
\qquad(\mathrm{g} / \mathrm{kg} \mathrm{DM})\end{array}$} \\
\hline & Low & High & s.e.d. & 0 & 28 & 56 & s.e.d. \\
\hline & & & & & & & \\
\hline g/day & 890 & 657 & $36 \cdot 9$ & 732 & 800 & 789 & $45 \cdot 1$ \\
\hline $\mathrm{g} / \mathrm{kg} \mathrm{M}^{0.75}$ & 57 & 42 & $2 \cdot 1$ & 47 & 51 & 50 & $2 \cdot 5$ \\
\hline $\begin{array}{l}\text { Total dry-matt } \\
\text { intake }\end{array}$ & & & & & & & \\
\hline g/day & 978 & 1027 & $38 \cdot 4$ & 958 & 1029 & 1021 & $47 \cdot 0$ \\
\hline $\mathrm{g} / \mathrm{kg} \mathrm{M}^{0.75}$ & 62 & 65 & $2 \cdot 1$ & 62 & 65 & 64 & $2 \cdot 6$ \\
\hline $\begin{array}{l}\text { Digestible orga } \\
\text { intake }\end{array}$ & & & & & & & \\
\hline g/day & 608 & 659 & $24 \cdot 4$ & 603 & 655 & 642 & $29 \cdot 9$ \\
\hline $\mathrm{g} / \mathbf{k g ~} \mathbf{M}^{0.75}$ & 39 & 42 & $1 \cdot 3$ & 39 & 41 & 41 & $1 \cdot 6$ \\
\hline
\end{tabular}


TABLE 5

Effect of level of concentrate offered and fish-meal supplementation on live-weight gain, food conversion ratio, carcass gain and killing-out proportion

\begin{tabular}{|c|c|c|c|c|c|c|c|}
\hline & \multicolumn{3}{|c|}{ Level of concentrate } & \multicolumn{4}{|c|}{$\begin{array}{l}\text { Fish meal supplementation } \\
\qquad(\mathrm{g} / \mathrm{kg} \text { DM })\end{array}$} \\
\hline & Low & High & s.e.d. & 0 & 28 & 56 & s.e.d. \\
\hline Initial live weight (kg) & $35 \cdot 3$ & $35 \cdot 4$ & $0 \cdot 65$ & $35 \cdot 1$ & $35 \cdot 4$ & $35 \cdot 5$ & $0 \cdot 80$ \\
\hline Final live weight (kg) & $42 \cdot 9$ & $43 \cdot 4$ & $1 \cdot 03$ & $41 \cdot 5$ & $43 \cdot 9$ & $44 \cdot 1$ & $1 \cdot 26$ \\
\hline \multicolumn{8}{|l|}{ Daily live-weight gain (g) } \\
\hline Day 1 to 22 & 197 & 178 & $19 \cdot 1$ & 165 & 188 & 208 & $23 \cdot 4$ \\
\hline Day 22 to 42 & 152 & 196 & $17 \cdot 3$ & 128 & 208 & 187 & $21 \cdot 1$ \\
\hline Day 1 to 42 & 171 & 192 & $14 \cdot 7$ & 151 & 196 & 197 & $17 \cdot 9$ \\
\hline \multicolumn{8}{|l|}{ Food conversion ratio } \\
\hline (g DM per g live-weight gain) & $5 \cdot 8$ & $5 \cdot 7$ & 0.40 & $6 \cdot 8$ & $5 \cdot 4$ & $5 \cdot 0$ & $0 \cdot 50$ \\
\hline Carcass weight (kg) & $19 \cdot 0$ & $19 \cdot 7$ & 0.25 & $18 \cdot 8$ & $19 \cdot 5$ & $19 \cdot 7$ & $0 \cdot 31$ \\
\hline Carcass gain (g/day) & 91 & 107 & $6 \cdot 0$ & 86 & 102 & 108 & $7 \cdot 4$ \\
\hline Killing-out proportion & $0 \cdot 444$ & $0 \cdot 454$ & 0.038 & 0.451 & 0.445 & $0 \cdot 449$ & $0 \cdot 047$ \\
\hline
\end{tabular}

TABLE 6

Effect of level of concentrate and fish-meal supplementation on nitrogen $(N)$ balance

\begin{tabular}{|c|c|c|c|c|c|c|c|}
\hline & \multicolumn{3}{|c|}{ Level of concentrate } & \multicolumn{4}{|c|}{$\begin{array}{l}\text { Fish meal supplementation } \\
\qquad(\mathrm{g} / \mathrm{kg} \mathrm{DM})\end{array}$} \\
\hline & Low & High & s.e.d. & 0 & 28 & 56 & s.e.d. \\
\hline $\mathrm{N}$ intake (g/day) & $20 \cdot 6$ & $23 \cdot 0$ & $0 \cdot 72$ & $19 \cdot 7$ & $22 \cdot 5$ & $23 \cdot 2$ & 0.92 \\
\hline Faecal N (g/day) & $8 \cdot 6$ & $10 \cdot 3$ & $0 \cdot 56$ & $8 \cdot 6$ & $9 \cdot 8$ & $10 \cdot 0$ & $0 \cdot 74$ \\
\hline Urinary $N$ (g/day) & $4 \cdot 1$ & $3 \cdot 6$ & $0 \cdot 64$ & $4 \cdot 4$ & $3 \cdot 9$ & $3 \cdot 4$ & 0.84 \\
\hline $\mathrm{N}$ retained (g/day) & $7 \cdot 8$ & $9 \cdot 1$ & 0.55 & $6 \cdot 7$ & $8 \cdot 8$ & 9.9 & $0 \cdot 72$ \\
\hline
\end{tabular}

N retention $(P<0.01)$. Again the majority of the response was associated with the intermediate level of supplementation.

When the $\mathrm{N}$ balance data were examined with DM intake as a covariate, any effects of level of supplementation disappeared. However, fish meal supplementation continued to provide greater $\mathbf{N}$ intakes and greater $\mathrm{N}$ retention $(P<0 \cdot 05)$.

\section{DISCUSSION}

The DM intakes achieved by the lambs were surprisingly high. The ARC (1980) proposed that the intake of coarse diets by sheep of this live weight should be about $60 \mathrm{~g} / \mathrm{kg} \mathrm{M}^{0 \cdot 75}$, with the exception of silage diets which should be about $46 \mathrm{~g} / \mathrm{kg} \mathrm{M}^{0.75}$. Thus the sheep in this experiment responded to maize silage-based diets as they might have done to diets based on roughages other than silage. The higher level of concentrate did lead to marked substitution for silage, such that the differences in total DM intake between the lower and higher levels of supplement was not statistically significant.
The inclusion of fish meal in the diets resulted in a substantial improvement in the conversion of DM to live-weight gain. To illustrate the nature of this effect, the live-weight gains predicted from the measured intakes of $\mathrm{ME}$, compared with the observed gains, are shown in Table 7. Some small differences between predicted and achieved gains occurred in the absence of fish meal supplements but the discrepancies in favour of achieved gains increased substantially when fish-meal supplements were provided. This effect was particularly marked with the higher level of concentrate supplement, when the improvement over the predicted values increased by up to one-third. These results substantiate similar findings published previously (Tayer and Bryant 1988) and provide further evidence in support of the contribution of Hovell and Ørskov (1989) that lambs have a potential for growth that cannot be met by conventional diets that fail to provide substantial supplies of UDN.

Although the interaction term between concentrate level and fish-meal supplement in the analyses of variance failed to reach statistical significance, the 
TABLE 7

Effect of level of concentrate offered and fish meal supplementation on predicted and achieved live-weight gains

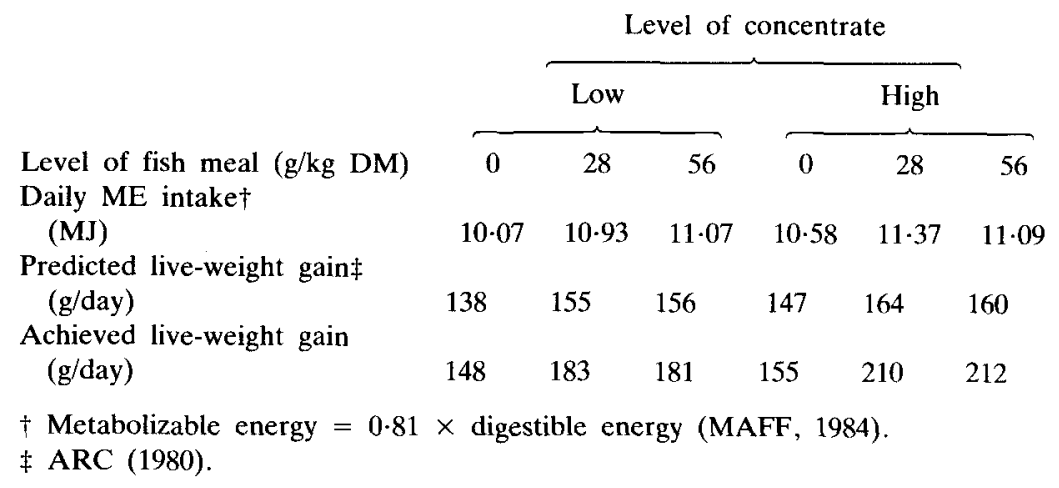

trends indicated by the treatment means presented in Table 7 do suggest that such an interaction occurred.

While both concentrate level and fish-meal supplements promoted greater carcass gains, neither proved to be cost-effective. The relative food costs (1988 prices) per $\mathrm{kg}$ carcass gain when diet 1 (low concentrate level, no fish meal) is represented by 100 , were 100,114 , $121,154,134$ and 138 for diets 1 to 6 , respectively. Thus, by this simple economic standard, the minimal supplementation represented by diet 1 , with its associated modest gains, proved most attractive. Because of the high substitution rate of concentrate for silage, the provision of the higher level of concentrate appeared to be particularly disadvantageous.

A common health problem associated with sheep given silage-based diets is listeriosis. This bacterial infection is reputed to be particularly prevalent with maize silage. For this reason it has been recommended that the proportional inclusion of maize silage in sheep diets should be restricted to $0 \cdot 2$. (Animal Research Institute, 1980). No health problems were encountered in this experiment although previous research at this centre has highlighted the risks of feeding maize silage to adult sheep (Mutisi, 1984).

In conclusion, this experiment showed that lambs readily ate maize silage-based diets. However, the most cost-effective gains were obtained with diets where supplementation was kept to the minimum.

\section{REFERENCES}

Agricultural Research Council. 1980. The Nutrient Requirements of Ruminant Livestock. Commonwealth Agricultural Bureaux, Slough.

Agricultural Research Council. 1984. The Nutrient Requirements of Ruminant Livestock.
Supplement No. 1. Commonwealth Agricultural Bureaux, Slough.

Animal Research Institute. 1980. Research for an intensive total confinement sheep production system. Technical Bulletin, Animal Research Institute, Agriculture, Canada, No. 2.

HASSAN, S. A. and BRyANT, M. J. 1986a. The response of store lambs to dietary supplements of fish meal. 1. Effects of forage-to-concentrate ratio. Animal Production 42: 223-232.

Hassan S. A. and Bryant, M. J. 1986b. The response of store lambs to dietary supplements of fish meal. 2. Effects of level of feeding. Animal Production 42: 233-240.

Hovell, F. D. DeB. and $\emptyset_{\text {RSkov, E. R. 1989. The role }}$ of fish meal in rations for sheep. International Association of Fish Meal Manufacturers, No. 23, March.

Ministry of Agriculture, Fisherifs and Food, Department of Agriculture for Scotland and Department OF Agriculture FOr Northern Ireland. 1984. Energy allowances and feeding systems for ruminants. Technical Bulletin 433. Her Majesty's Stationery Office, London.

Mutisi, C. 1984. Problems of feeding maize silage to pregnant sheep. Ph.D. Thesis, University of Reading.

TAYER, S. R. and BRyAnT, M. J. 1988. The response of store lambs to dietary supplements of fish meal. 3 . Effects of the preceding pattern of growth. Animal Production 47: 393-399.

Yilala, K. and Bryant, M. J. 1985. The effects upon the intake and performance of store lambs of supplementing grass silage with barley. fish meal and rapeseed meal. Animal Production 40: 111121. 